\title{
TEKNIK MITIGASI RISIKO PEMBIAYAAN PEMILIKAN RUMAH (PPR) SYARIAH PADA DEVELOPER PROPERTI SYARIAH
}

\author{
Nur Sa'diyah \\ Departemen Ekonomi Syariah - Fakultas Ekonomi dan Bisnis - Universitas Airlangga \\ Email: nur.sadiyah-2015@feb.unair.ac.id \\ Noven Suprayogi \\ Departemen Ekonomi Syariah - Fakultas Ekonomi dan Bisnis - Universitas Airlangga \\ Email: noven.suprayogi@feb.unair.ac.id
}

\begin{abstract}
:
The purpose of this study is to find out the technique of risk mitigation in home ownership financing (PPR) conducted by PT Indo Tata Graha. This study uses qualitative approach with descriptive case study strategy. The data in this study were obtained through primary data in the form of interviews and secondary data in the form of documentation. The results of this study indicate that the risk of home ownership financing (PPR) consists of risks of cancel, default risk, risk of miss manage and the risk of delays in the delivery of goods). To minimize the occurrence of losses and impacts due to risk. Sharia Property Developer has risk mitigation carried out which is divided into two stages, namely before the occurrence of risk and after the occurrence of risk.
\end{abstract}

Keywords: house ownership financing (PPR), PT Indo Tata Graha, risk in house ownership financing, risk mitigation of sharia property developer

I. PENDAHULUAN

Menurut Badan Pusat Statistik

(2015), penduduk Indonesia setiap tahunnya memiliki kebutuhan rumah sebesar 800.000 unit, sementara pemerintah dan pengembang (developer) hanya dapat memenuhi kebutuhan kepemilikan rumah sebanyak 400.000 unit per tahun. Tercatat angka backlog (kesenjangan) kepemilikan rumah tahun 2010 di Indonesia mencapai angka 13,6 juta unit dan angka backlog kepemilikan rumah masih ada sekitar 1.244.421 rumah tangga di Jawa Timur. Dengan demikian semakin tingginya pertumbuhan penduduk inilah yang membuat permintaan kebutuhan mengenai kepemilikan tempat tinggal semakin tinggi dan kesenjangan kepemilikan rumah cukup besar.

Berdasarkan hal tersebut, banyak cara yang dilakukan oleh masyarakat agar dapat memenuhi kebutuhan dalam memiki tempat tinggal melalui lembagalembaga yang ada di Indonesia, baik lembaga keuangan maupun lembaga non-keuangan. Tingginya permintaan kebutuhan kepemilikan rumah ini mendorong lembaga-lembaga terkait baik konvensional maupun syariah dalam memberikan penawaran akses yang mudah bagi masyarakat dalam memperoleh hunian yang layak dan harga yang dapat dijangkau. Untuk menghindari transaksi yang mengandung riba, masyarakat dapat mengambil

\footnotetext{
${ }^{1}$ Jurnal ini adalah bagian dari skripsi yang ditulis oleh Nur Sa'diyah, NIM: 04151 1433040, yang diuji pada tanggal 22 Juli 2019.
} 
Sa'diyah, et al/Jurnal Ekonomi Syariah Teori dan Terapan Vol. 6 No. 9 September 2019: 1814-1829; TEKNIK MITIGASI RISIKO PEMBIAYAAN PEMILIKAN RUMAH (PPR) SYARIAH PADA DEVELOPER PROPERTI SYARIAH

pembiayaan kepemilikan rumah melalui lembaga keuangan syariah maupun lembaga non-keuangan yang menganut prinsip syariah. Salah satunya adalah melalui Developer Properti Syariah (DPS). Pertumbuhan pasar di bidang properti akhirnya menjadi semakin meningkat sehingga menyebabkan muncul banyaknya developer property syariah (Firmansyah dan Gunardi, 2018). Hal ini ditunjukkan juga oleh jumlah dari Developer Properti Syariah saat ini telah mencapai lebih dari 100 Developer (DPSI, 2018).

Dalam melakukan kegiatan operasionalnya, Developer Properti Syariah tentu tidak akan lepas dari risikorisiko yang akan timbul di masa yang akan datang. Menurut Kountur (2008) risiko diartikan sebagai kemungkinan kejadian yang merugikan. Ada tiga unsur penting dari sesuatu yang dianggap sebagai risiko adalah suatu kejadian, kejadian tersebut masih merupakan kemungkinan, jadi bisa saja terjadi bisa tidak terjadi, dan jika sampai terjadi, akan menimbulkan kerugian. Menurut Nugroho (2013) semakin besar sebuah developer properti maka akan semakin besar pelvang dan risiko yang akan dihadapi. Hal ini juga didukung oleh konsep tagline Developer Properti Syariah Indonesia (DPSI) yang menerapkan pembiayaan kepada konsumen Tanpa Bank, Tanpa Bunga, Tanpa Denda dan Sita, dan Tanpa Bl Checking. Konsep ini tentunya bertolak belakang dengan penerapan pembiayaan yang ada di lembaga kevangan seperti Bank dan developer properti syariah belum memiliki lembaga penjamin dan regulasi yang mengatur di dalam pembiayaannya.

Oleh karena itu, developer properti syariah memiliki tingkat risiko yang tinggi sehingga membuat pihak dari developer properti syariah lebih memikirkan keberlangsungan usahanya dan menuntut perusahaan untuk menerapkan mitigasi risiko yang tepat dan sesuai agar risiko yang akan dihadapi maupun yang sedang dihadapi dapat ditangani dengan tepat dan dapat dikurangi dampak negatifnya. Menurut Aditya dan Naomi (2017) isu mengenai pentingnya pengelolaan risiko pada perusahaan menjadi sebuah perhatian yang cukup serius di berbagai sektor industri di Indonesia.

PT Indo Tata Graha merupakan developer properti syariah yang didirikan pada tahun 2014 dan merupakan developer properti syariah pertama dan terbesar di Jawa Timur. PT Indo Tata Graha memiliki produk pembiayaan pemilikan rumah (PPR) Syariah menggunakan akad istishna' dan salam. Berdasarkan uraian di atas, ingin mengetahui bagaimana penerapan teknik mitigasi risiko pembiayaan pemilikan rumah (PPR) pada Developer Properti Syariah PT Indo Tata Graha.

\section{TINJAUAN PUSTAKA}

Pembiayaan Pemilikan Rumah (PPR) pada umumnya adalah 
Sa'diyah, et al/Jurnal Ekonomi Syariah Teori dan Terapan Vol. 6 No. 9 September 2019: 1814-1829; TEKNIK MITIGASI RISIKO PEMBIAYAAN PEMILIKAN RUMAH (PPR) SYARIAH PADA DEVELOPER PROPERTI SYARIAH

pembiayaan konsumen. Pembiayaan konsumen adalah suatu kegiatan pembiayaan dalam rangka pengadaan barang berupa rumah, berdasarkan kebutuhan konsumen melalui pembayaran secara angsuran/cicilan dengan jaminan berupa rumah yang dilakukan oleh bank (Idris, 2014). Pembiayaan berdasarkan prinsip syariah dalam UU No.10 Tahun 1998 adalah penyediaan uang maupun tagihan berdasarkan kesepakatan antara bank dengan pihak lain yang mewajibkan pihak yang diberikan pembiayaan memiliki kewajiban untuk mengembalikan vang atau tagihan tersebut setelah jangka waktu tertentu disertai bagi hasil atau imbalan.

Berdasarkan Surat Edaran Bank Indonesia Nomor 14/33/DPBS, pada umumnya akad-akad yang digunakan dalam produk pembiayaan pemilikan rumah (PPR) syariah oleh Bank ada empat, yaitu Murabahah, Musyarakah Mutanaqisah (MMQ), ljarah Muntahiya BitTamlik (IMBT) dan Istishna'.

Alijoyo (2006:3) menjelaskan risiko dari sudut pandang hasil dan proses. Definisi dari sudut pandang hasil adalah Sebuah hasil atau keluaran yang tidak dapat diprediksikan dengan pasti dimana tidak disukai karena akan menjadi kontra produktif. Definisi risiko dari sudut pandang proses adalah faktor-faktor yang dapat mempengaruhi pencapaian tujuan, sehingga terjadinya konsekuensi yang tidak diinginkan.
Islam memandang bahwa risiko merupakan sebuah sunnatullah dalam sebuah bisnis. Risiko dalam bisnis tidak dapat dihilangkan, tetapi bisa dikelola sehingga dampak dari risiko tersebut dapat diminimalkan. Setiap usaha yang dilakukan manusia tidak terlepas dari adanya risiko. Manusia hanya bisa mengusakan dan berdo'a supaya yang di usahakan bisa tercapai, sedangkan hasil dari usaha tersebut hanya Allah yang menetukan. Hal ini sesuai dengan firmanAllah dalam Al Qur'an surat Luqman ayat 34 :

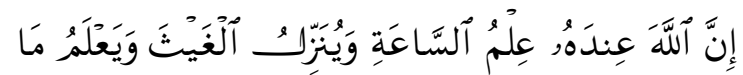

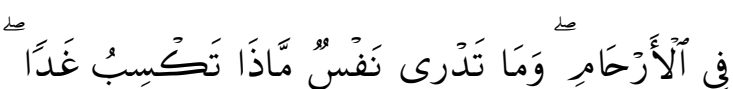

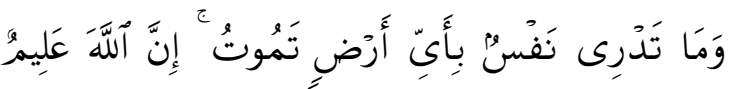
خَبِيرِ

innallāha 'indahụ 'ilmus-sā'ah, wa yunazzilul-gaīs, wa ya'lamu mā fil-ar-hām, wa mā tadrī nafsum māżā taksibu gadā, wa mā tadrī nafsum bi ayyi arọin tamụt, innallāha 'allimun khabìr

Artinya: Sesungguhnya Allah, hanya pada sisi-Nya sajalah pengetahuan tentang Hari Kiamat; dan Dialah Yang menurunkan hujan, dan mengetahui apa yang ada dalam rahim. Dan tiada seorangpun yang dapat mengetahui (dengan pasti) apa yang akan diusahakannya besok. Dan tiada seorangpun yang dapat mengetahui di bumi mana dia akan mati. Sesungguhnya Allah Maha Mengetahui lagi Maha Mengenal. 
Sa'diyah, et al/Jurnal Ekonomi Syariah Teori dan Terapan Vol. 6 No. 9 September 2019: 1814-1829; TEKNIK MITIGASI RISIKO PEMBIAYAAN PEMILIKAN RUMAH (PPR) SYARIAH PADA DEVELOPER PROPERTI SYARIAH

Berdasarkan ayat di atas, penegasan Allah bahwa tidak ada seorangpun yang dapat mengetahui dengan pasti apa yang dikerjakannya besok serta dampak dan hasil usahanya. Dan tidak ada seorangpun yang mengetahui secara pasti lokasi dan kapan dia akan meninggal (Shihab, t.t). Oleh karena itu, dapat disimpulkan bahwa dalam suatu ketidakpastian akan terkandung risiko.

Menurut Lestari (2014) risiko pembiayaan biasanya dikaitkan degan risiko gagal bayar (terlambat bayar) Risiko gagal bayar (terlambat bayar) ini akan menimbulkan potensi kerugian yang dihadapi oleh bank ketika pembiayaan yang diberikan kepada nasabahnya itu macet. Selain kesulitan dalam pengembalian modal, risiko ini juga meliputi ketidakmampuan debitur dalam memberikaan porsi keuntungan atau imbal hasil untuk bank sebagaimana sesuai dengan kesepakatan awal. Risiko ini berlaku pada pembiayaan istishna'. Selain risiko gagal bayar (terlambat bayar), pembiayaan menggunakan akad istishna'memiliki beberapa risiko lain yang dapat timbul seperti kegagalan kontraktor dalam menyediakan rumah pada waktu yang telah ditentukan, dan spesifikasi rumah yang kurang sesuai dengan perjanjian pada kesepakatan awal.

Manajemen risiko menurut Peraturan Bank Indonesia No. 13/23/PBI/201 1 tentang Penerapan Manajemen Risiko Bagi Bank Umum
Syariah dan Unit Usaha Syariah adalah serangkaian prosedur dan metode yang digunakan untuk mengidentifikasi, mengukur, memantau dan mengendalikan risiko yang timbul dari kegiatan usaha bank. Menurut Khan (2008:53) mitigasi merupakan proses mengidentifikasi dan memberikan pihak untuk bertanggung jawab atas setiap respon risiko. Hal ini memastikan bahwa setiap risiko yang membutuhkan respon ada pemiliknya. Pemilik risiko bisa menjadi perencana lembaga, insinyur, atau manajer konstruksi, tergantung pada titik dalam pengembangan proyek, atau bisa juga kontraktor swasta atau pasangan, tergantung metode kontrak dan alokasi risiko.

Mitigasi risiko pembiayaan menurut Rustam (2013) adalah beberapa teknik dan kebijakan dalam mengelola risiko pembiayaan yang bertujuan untuk meminimalkan kemungkinan terjadinya atau dampak dari kerugian pembiayaan yang dialami. The Committee of Sponsoring Organizations of the Treadway Commission (COSO) Integrated Framework (2004) menyebutkan ada 4 strategi mitigasi risiko dalam standar manajemen risiko (Dorian, 2011 :4), yaitu:

1. Avoid (menghindari risiko)

Beberapa risiko yang tidak layak berada di prioritas utama. Apakah risiko akibat kegagalan dalam bisnis ataukah dari luar bisnis. Jika diluar, dan tingkat risiko dianggap tinggi, maka pertimbangan harus diberikan untuk berhenti atau 
Sa'diyah, et al/Jurnal Ekonomi Syariah Teori dan Terapan Vol. 6 No. 9 September 2019: 1814-1829;

TEKNIK MITIGASI RISIKO PEMBIAYAAN PEMILIKAN RUMAH (PPR) SYARIAH PADA DEVELOPER PROPERTI SYARIAH

menghindari untuk melaksanakan kegiatan tersebut. Jika kegiatan berada di bagian dalam inti bisnis, maka dipertimbangkan apakah ada cara lain untuk melakukan hal-hal yang akan menghindari atau meminimalkan risiko atau kerugian.

2. Reduce (mengurangi risiko)

Pengurangan dan pencegahan risiko saling berkaitan erat dan pada dasarnya dapat dicapai dengan cara mengurangi atau menyingkirkan sebagian atau keseluruhan risiko yang ada. Dalam pelaksanaannya ada dua cara yang dapat digunakan, yaitu:

a. Eliminasi (Penghapusan Risiko), yaitu menghapuskan atau megurangi kemungkinan terjadinya risiko yang dihadapi

b. Minimisasi (memperkecil risiko), usaha untuk memperkecil risiko yang dapat dibagi dalam dua bagian, yaitu:

i. Pre Loss Minimisation, adalah suatu tindakan memperkecil terjadinya suatu risiko yang dilakukan sebelum terjadinya kerugian.

ii. Post Loss Minimisation, adalah suatu tindakan memperkecil terjadinya suatu risiko yang terjadi sesudah terjadinya kerugian

3. Share (berbagi/transfer risiko)

Transfer risiko adalah proses mentransfer kerugian yang timbul kepada pihak ketiga, seperti melalui pengunaan polis asuransi. Metode lain mentransfer risiko adalah untuk mensubkan kegiatan kepada pihak ketiga. Jika ada kegiatan yang inti untuk bisnis, maka mungkin lebih baik masuk akal untuk mentransfer kegiatan ini kepada pihak ketiga untuk bisnis inti perusahaan, terutama jika sumber daya internal terbatas.

4. Accept (menerima risiko)

Kontrol adalah prosedur yang digunakan untuk mencegah risiko baik dari yang terjadi atau mendeteksi risiko setelah terjadi. Jika risiko bernilai dan merupakan bagian dari kegiatan operasi inti, maka kontrol dapat digunakan untuk mengurangi dan mengelola risiko.

Berdasarkan Peraturan Bank Indonesia No.13/09/PBI/2011 tentang restrukturisasi pembiayaan bagi bank syariah dan unit usaha syariah. Restrukturisasi Pembiayaan adalah upaya yang dilakukan Bank dalam rangka membantu nasabah agar dapat menyelesaikan kewajibannya, antara lain melalui:

a. Penjadwalan kembali (rescheduling), yaitu perubahan jadwal pembayaran kewajiban nasabah atau jangka waktunya;

b. Persyaratan kembali (reconditioning), yaitu perubahan sebagian atau seluruh persyaratan Pembiayaan tanpa menambah sisa pokok kewajiban nasabah yang harus dibayarkan kepada Bank, antara lain meliputi:

1) perubahan jadwal pembayaran;

2) perubahan jumlah angsuran;

3) perubahan jangka waktu; 
Sa'diyah, et al/Jurnal Ekonomi Syariah Teori dan Terapan Vol. 6 No. 9 September 2019: 1814-1829; TEKNIK MITIGASI RISIKO PEMBIAYAAN PEMILIKAN RUMAH (PPR) SYARIAH PADA DEVELOPER PROPERTI SYARIAH

4) perubahan nisbah dalam pembiayaan mudharabah atau musyarakah;

5) perubahan proyeksi bagi hasil dalam pembiayaan mudharabah atau musyarakah; dan/atau

6) pemberian potongan.

c. Persyaratan kembali (reconditioning), yaitu perubahan sebagian atau seluruh

d. Penataan kembali (restructuring), yaitu perubahan persyaratan Pembiayaan yang antara lain meliputi:

1) penambahan dana fasilitas Pembiayaan Bank;

2) konversi akad Pembiayaan;

3) konversi Pembiayaan menjadi surat berharga syariah berjangka waktu menengah; dan/atau

4) konversi Pembiayaan menjadi penyertaan modal sementara pada perusahaan nasabah, yang dapat disertai dengan rescheduling atau reconditioning.

\section{METODE PENELITIAN}

Metode yang digunakan dalam penelitian ini adalah kualitatif deskriptif. Penelitian ini bertujuan untuk mengeksplorasi dan memahami secara komprehensif mengenai bagaimana proses mitigasi risiko pembiayaan pemilikan rumah (PPR) syariah yang dilakukan oleh PT Indo Tata Graha Sidoarjo.

Menurut Nawawi (1990:64) metode penelitian deskriptif yaitu metode penelitian yang memusatkan perhatian pada masalah atau fenomena yang ada pada saat penelitian dilakukan atau masalah yang bersifat aktual, kemudian menggambarkan fakta-fakta tentang masalah yang diselidiki sebagaimana adanya diiringi dengan interpretasi yang rasional dan akurat. Arikunto (2003:310) menegaskan pula bahwa penelitian deskriptif tidak dimaksudkan untuk menguji hipotesis tertentu, tetapi hanya menggambarkan "apa adanya" tentang suatu variabel, gejala, atau keadaan. Dengan demikian, penelitian kualitatif deskriptif hanya menguraikan bagaimana situasi atau peristiwa yang diteliti.

\section{HASIL DAN PEMBAHASAN}

Risiko pembiayaan pemilikan rumah (PPR) pada developer properti syariah yang terjadi karena customer adalah risiko gagal bayar (terlambat bayar) Risiko gagal bayar adalah risiko yang terjadi jika ada keterlambatan pembayaran pada tanggal yang telah disepakati dan telah terjadi selama 3 bulan oleh customer yang disebabkan oleh alasan tertentu seperti di-PHK, sakit, bangkrut, dan musibah lainnya.. Konsep yang digunakan developer properti syariah ini selaras dengan Peraturan Bank Indonesia Nomor 13/23/PBI/201 1 tentang Penerapan Manajemen Risiko Bagi Bank Umum Syariah Dan Unit Usaha Syariah menyatakan bahwa Risiko Kredit adalah Risiko akibat kegagalan nasabah atau pihak lain dalam memenuhi kewajiban kepada Bank sesuai dengan perjanjian yang disepakati.

Menurut Ismail (2010) Kredit bermasalah merupakan kredit yang telah 
Sa'diyah, et al/Jurnal Ekonomi Syariah Teori dan Terapan Vol. 6 No. 9 September 2019: 1814-1829;

TEKNIK MITIGASI RISIKO PEMBIAYAAN PEMILIKAN RUMAH (PPR) SYARIAH PADA DEVELOPER PROPERTI SYARIAH

disalurkan oleh bank, dan nasabah tidak dapat melakukan pembayaran atau tidak melakukan angsuran sesuai dengan perjanjian yang telah ditandatangani oleh bank dan nasabah. Kredit non-performing merupakan kredit yang sudah dikategorikan kredit bermasalah, karena sudah terdapat tunggakan. Kredit nonperforming dikelompokkan menjadi tiga kategori, yaitu:

1. Kredit kurang lancar merupakan kredit yang mengalami tunggakan. Yang tergolong kredit kurang lancar apabila pengembalian pokok pinjaman dan bunganya mengalami penundaan pembayaran melampaui 90 hari sampai dengan kurang dari 180 hari.

2. Kredit diragukan merupakan kredit yang mengalami penundaan pembayaran pokok dan/atau bunga. Yang tergolong kredit diragukan apabila penundaan pembayaran pokok dan/atau bunga antara 180 hingga 270 hari.

3. Kredit macet merupakan kredit yang menunggak melampaui 270 hari atau lebih. Bank akan mengalami kerugian atas kredit macet tersebut.

Risiko gagal bayar (terlambat bayar) pada developer properrti syariah merupakan risiko kredit yang termasuk ke dalam kredit kurang lancar. Developer menggolongkan sebuah pembiayaan dikatakan gagal bayar apabila customer telah melakukan penundaan pembayaran selama 90 hari (3 bulan).
Berdasarkan penelitian kepada informan diketahui bahwa terjadinya risiko gagal bayar (terlambat bayar) disebabkan oleh beberapa hal yaitu diPHK, sakit, bangkrut, dan musibah lainnya.

Keterlambatan pembayaran oleh customer dapat terjadi karena customer karena customer mengalami kebangkrutan sehingga customer harus mencari dan menemukan pekerjaan baru. Hal ini membuat customer mengalami penurunan dalam kemampuan membayar kewajibannya. Terkena PHK merupakan penyebab terjadinya risiko gagal bayar karena customer kehilangan pekerjaannya dan membutuhkan waktu untuk memiliki pekerjaan yang baru sehingga dalam kondisi ini customer kemampuan membayar kewajibannya menjadi menurun. Customer yang terkena musibah sakit pun juga menjadi penyebab terjadinya risiko gagal bayar karena customer tidak bisa memenuhi kewajibannya karena kondisi yang kurang baik atau biaya perawatan yang cukup mahal menjadikan customer mengalami kesusahan dalam membayar kewajiban.

Risiko pembiayaan pemilikan rumah (PPR) pada developer properti syariah lainnya adalah risiko cancel (pembatalan pembelian). Risiko cancel adalah risiko yang terjadi jika salah satu pihak tidak dapat melanjutkan akad karena alasan tertentu seperti meninggal , sakit, pindah, dan alasan syar'i lainnya sehingga tidak dapat memenuhi 
Sa'diyah, et al/Jurnal Ekonomi Syariah Teori dan Terapan Vol. 6 No. 9 September 2019: 1814-1829; TEKNIK MITIGASI RISIKO PEMBIAYAAN PEMILIKAN RUMAH (PPR) SYARIAH PADA DEVELOPER PROPERTI SYARIAH

kewajiban yang telah ditetapkan atau melanggar ketentuan-ketentuan yang ada.. Konsep yang digunakan developer properti syariah ini selaras dengan Peraturan Bank Indonesia Nomor 13/23/PBI/2011 tentang Penerapan Manajemen Risiko Bagi Bank Umum Syariah Dan Unit Usaha Syariah menyatakan bahwa Risiko Kredit adalah Risiko akibat kegagalan nasabah atau pihak lain dalam memenuhi kewajiban kepada Bank sesuai dengan perjanjian yang disepakati.

Risiko cancel (pembatalan pembelian) ini terjadi karena customer sudah tidak dapat lagi melanjutkan akad atau memenuhi kewajibannya sebagaimana telah disepakati. Terjadinya risiko cancel (pembatalan pembelian) disebabkan oleh beberapa hal seperti meninggal, sakit, pindah rumah, dan alasan syar'i lainnya.

Risiko cancel dapat terjadi karena apabila customer yang melakukan akad dengan developer ternyata meninggal dunia maka customer dinyatakan tidak bisa melanjutkan dan akad batal. Customer yang terkena musibah sakit yang dapat mengakibatkan kecacatan seumur hidup sehingga tidak dapat melanjutkan memenuhi kewajibannya juga merupakan penyebab terjadinya risiko cancel. Hal ini terjadinya karena customer sudah tidak memiliki kemampuan dalam memenuhi kewajibannya sehingga tidak bisa bekerja misalnya. Melakukan perubahan domisili atau pindah rumah juga menjadi penyebab terjadinya risiko cancel atau pembatalan pembelian karena customer tidak bisa menghuni rumah yang menjadi objek perjanjian/akad tersebut kembali dan harus berpindah ke tempat lain.

Risiko yang dapat terjadi pada pembiayaan pemilikan rumah (PPR) pada developer properti syariah ini adalah risiko yang berasal dari customer yaitu risiko gagal bayar (terlambat bayar) dan risiko cancel. Kedua risiko tersebut selaras dengan konsep risiko kredit pada bank yaitu risiko akibat kegagalan nasabah atau pihak lain dalam memenuhi kewajiban kepada Bank sesuai dengan perjanjian yang disepakati. Akan tetapi, developer properti syariah memiliki dua risiko kredit yang berbeda. Risiko tersebut dikategorikan berdasarkan penyebab terjadinya risiko.

Terjadinya risiko gagal bayar (terlambat bayar) disebabkan oleh beberapa hal yaitu di-PHK, sakit, bangkrut, dan musibah lainnya sehingga jika terjadi risiko ini, customer masih dianggap dapat melanjutkan perjanjian akan tetapi mengalami keterlambatan pembayaran. Sedangkan, risiko cancel (pembatalan pembelian) ini terjadi karena customer sudah tidak dapat lagi melanjutkan akad atau memenuhi kewajibannya sebagaimana telah disepakati. Terjadinya risiko cancel (pembatalan pembelian) disebabkan oleh beberapa hal seperti meninggal, sakit, pindah rumah, dan alasan syar'i lainnya sehingga apabila 
Sa'diyah, et al/Jurnal Ekonomi Syariah Teori dan Terapan Vol. 6 No. 9 September 2019: 1814-1829; TEKNIK MITIGASI RISIKO PEMBIAYAAN PEMILIKAN RUMAH (PPR) SYARIAH PADA DEVELOPER PROPERTI SYARIAH

risiko ini terjadi, maka customer memang sudah tidak bisa melanjutkan perjanjian yang telah disepaati dengan developer properti syariah.

Risiko pembiayaan pemilikan rumah (PPR) pada developer properti syariah tidak hanya berasal dari customer saja, akan tetapi juga dapat disebabkan oleh perusahaan developer. Risiko-risiko tersebut adalah risiko salah manajemen (miss manage) dan risiko keterlambatan penyerahan barang. Risiko salah manajemen (miss manage) adalah risiko yang terjadi karena pihak developer properti syariah melakukan kesalahan dalam perhitungan, prediksi kondisi pasar, hingga kesalahan dalam mempercayakan rekan kerja untuk menyelesaikan proyek. Sedangkan, risiko keterlambatan penyerahan barang adalah risiko yang terjadi karena developer terlambat dalam menyerahkan barang pada waktu yang telah dijanjikan karena kelangkaan barang dan kondisi tertentu lainnya

Konsep risiko pembiayaan pemilikan rumah yang disebabkan oleh perusahaan developer ini sesuai dengan Peraturan Bank Indonesia Nomor 13/23/PBI/2011 Tentang Penerapan Manajemen Risiko Bagi Bank Umum Syariah Dan Unit Usaha Syariah menjelaskan bahwa Risiko Operasional adalah Risiko kerugian yang diakibatkan oleh proses internal yang kurang memadai, kegagalan proses internal, kesalahan manusia, kegagalan sistem, dan/atau adanya kejadian eksternal yang mempengaruhi operasional Bank.

Berdasarkan penelitian yang dilakukan kepada informan, risiko salah manajemen (miss manage) dapat terjadi karena pihak developer properti syariah melakukan kesalahan dalam perhitungan, prediksi kondisi pasar, hingga kesalahan dalam mempercayakan rekan kerja untuk menyelesaikan proyek. Kesalahan dalam perhitungan baik dari bahan material bangunan hingga perhitungan dalam analisis pembiayaan menjadi penyebab terjadinya risiko miss manage (salah manajemen) sehingga dapat mengakibatkan kerugian dan perusahaan tidak dapat mencapai tujuan sebagaimana mestinya karena yang dilaksanakan berbeda dengan apa yang telah direncanakan. Kesalahan dalam memprediksi pasar membuat developer menjadi rugi karena kesalahan prediksi ini dapat mempengaruhi penjualan dari produk yang sedang ditawarkan kepada customer.

Kesalahan

dalam mempercayakan rekan kerja untuk menyelesaikan proyek juga menjadi salah satu penyebab terjadinya risiko risiko miss manage (salah manajemen) karena developer salah memilih rekan kerja sehingga dapat terjadi wanpretasi yang dilakukan oleh rekan kerja dan mengakibatkan kerugian bagi developer. Risiko yang berasal dari perusahaan lainnya adalah risiko keterlambatan penyerahan barang di mana risiko ini 
Sa'diyah, et al/Jurnal Ekonomi Syariah Teori dan Terapan Vol. 6 No. 9 September 2019: 1814-1829; TEKNIK MITIGASI RISIKO PEMBIAYAAN PEMILIKAN RUMAH (PPR) SYARIAH PADA DEVELOPER PROPERTI SYARIAH

terjadi karena keterlambatan developer dalam menyerahkan barang pada waktu yang telah dijanjikan karena kelangkaan barang dan kondisi tertentu.

Kelangkaan barang atau material bangunan menjadi salah satu penyebab risiko keterlambatan penyerahan barang yang disebabkan oleh pihak developer tidak dapat menyelesaikan pembangunan rumah customer karena bahan bangunan yang telah disepakati di awal perjanjian terjadi kelangkaan sehingga developer mengalami hambatan dalam menyelesaikan dan menyerahkan bangunan rumah milik customer pada waktu yang telah disepakati.

Berdasarkan Peraturan Bank Indonesia No.13/09/PBI/2011 tentang restrukturisasi pembiayaan bagi bank syariah dan unit usaha syariah menyatakan bahwa dalam rangka menjaga kelangsungan usaha dan meminimalisasi risiko kerugian, Bank Syariah dan Unit Usaha Syariah berkewajiban menjaga kualitas pembiayaan. Salah satu upaya yang dilakukan dalam menjaga kualitas pembiayaan adalah melakukan restrukturisasi pembiayaan terhadap nasabah. Restrukturisasi Pembiayaan adalah upaya yang dilakukan Bank dalam rangka membantu nasabah agar dapat menyelesaikan kewajibannya. Konsep ini juga digunakan oleh developer properti syariah dalam mengurangi terjadinya kerugian yang disebabkan oleh risiko kredit yaitu risiko gagal bayar pada pembiayaan pemilikan rumah. Developer properti syariah menggunakan teknik mitigasi risiko berupa restrukturisasi pembiayaan dalam membantu customer untuk menyelesaikan kewajibannya sebagaimana sesuai dengan apa yang dilakukan oleh Bank Syariah juga.

Berdasarkan konsep tersebut, developer properti syariah menggunakan dua cara restrukturisasi pembiayaan bagi customer yang mengalami risiko kredit atau risiko gagal bayar yaitu rescheduling dan reconditioning. Developer properti syariah dalam upaya mitigasinya adalah melakukan prosedur sesuai IJB dengan memberikan tambahan waktu angsuran kepada customer yang menunggak pembayaran angsuran (rescheduling) memberikan kesempatan kepada customer untuk membayar secara rangkap pada bulan selanjutnya yaitu saat customer sudah bisa mengangsur (reconditioning).

Risiko kredit lainnya yang dihadapi oleh developer properti pada pembiayaan pemilikan rumah yaitu risiko cancel (pembatalan pembelian). Risiko cancel (pembatalan pembelian) adalah risiko yang terjadi jika salah satu pihak tidak dapat melanjutkan akad karena alasan tertentu seperti meninggal, sakit, pindah rumah, dan alasan syar'i lainnya sehingga tidak dapat memenuhi kewajiban yang telah ditetapkan atau melanggar ketentuan-ketentuan yang ada. Risiko ini memungkinkan customer 
Sa'diyah, et al/Jurnal Ekonomi Syariah Teori dan Terapan Vol. 6 No. 9 September 2019: 1814-1829; TEKNIK MITIGASI RISIKO PEMBIAYAAN PEMILIKAN RUMAH (PPR) SYARIAH PADA DEVELOPER PROPERTI SYARIAH

sudah benar-benar tidak dapat melanjutkan perjanjian pembiayaan atau memenuhi kewajibannya.

Mitigasi risiko yang dilakukan oleh developer pada saat terjadinya risiko cancel oleh customer ini adalah tidak melakukan sita, melainkan melaksanakan prosedur sesuai IJB (Ikatan Jual Beli) yang sudah disepakati oleh kedua belah pihak di awal akad. Prosedur tersebut meliputi 2 opsi refund yaitu pihak developer properti syariah akan memberikan refund 100\% setelah unit milik customer tesebut terjual atau jika unitnya belum terjual maka pihak developer properti syariah akan merefund $100 \%$ uang milik customer dan dipotong dengan biaya komisi marketing.

Menurut Amir (2017) menyatakan bahwa pembiayaan yang diberikan bank sealu memiliki potensi risiko yang dapat menyebabkan pembiayaan tersebut bermasalah. Upaya dari perbankan syariah untuk mengurangi risiko yang timbul dalam menangani pembiayaan bermasalah adalah restrukturisasi pembiayaan, jaminan eksekusi, dan penyelesaian melalui pengadilan. Metode yang paling efektif dalam menangani pembiayaan bermasalah adalah penjuaan barang agunan tersebut yang digunakan untuk membayar kembali pembiayaan.

Berdasarkan konsep developer properti syariah dalam mengatasi risiko kredit (cancel) yang disebabkan oleh customer tidak selaras dengan konsep Bank dalam menangani pembiayaan bermasalah. Developer properti syariah tidak menggunakan jaminan pada pembiayaan sehingga jika terjadi ketidakmampuan customer dalam memenuhi kewajiban atau melanjutkan pembiayaan karena alasan syar'i maka barang yang dijadikan objek akad dapat dijual dan pihak developer akan mengembalikan (refund) dana yang telah dibayarkan oleh customer selama pembiayaan. Sedangkan pada Bank Syariah, apabila terjadi masalah pada pembiayaan maka Bank Syariah akan melakukan penjualan jaminan. Hal ini dilakukan karena pihak Bank Syariah menggunakan jaminan dalam pembiayaannya.

Developer properti syariah tidak hanya mengalami risiko kredit berupa risiko gagal bayar saja dalam melakukan kegiatan pembiayaan pemilikan rumah. Risiko lain yang dihadapi oleh developer adalah risiko operasional. Risiko operasional terdiri dari risiko miss manage (kesalahan manajemen) dan risiko keterlambatan penyerahan barang. Penyebab terjadinya risiko salah manajemen (miss manage) adalah karena pihak developer properti syariah melakukan kesalahan dalam perhitungan, prediksi kondisi pasar, hingga kesalahan dalam mempercayakan rekan kerja untuk menyelesaikan proyek. Terjadinya kelangkaan barang atau material bangunan menjadi salah satu penyebab risiko keterlambatan penyerahan barang yang disebabkan oleh pihak developer 
Sa'diyah, et al/Jurnal Ekonomi Syariah Teori dan Terapan Vol. 6 No. 9 September 2019: 1814-1829; TEKNIK MITIGASI RISIKO PEMBIAYAAN PEMILIKAN RUMAH (PPR) SYARIAH PADA DEVELOPER PROPERTI SYARIAH

tidak dapat menyelesaikan pembangunan rumah customer karena bahan bangunan yang telah disepakati di awal perjanjian terjadi kelangkaan sehingga developer mengalami hambatan dalam menyelesaikan dan menyerahkan bangunan rumah milik customer pada waktu yang telah disepakati. Upaya penanganan risiko telah dituntun oleh Allah pada surat Yusuf ayat 46-47 yang artinya

"(Setelah pelayan itu berjumpa dengan Yusuf dia berseru): "Yusuf, hai orang yang amat dipercaya, terangkanlah kepada kami tentang tujuh ekor sapi betina yang gemuk-gemuk yang dimakan oleh tujuh ekor sapi betina yang kurus-kurus dan tujuh bulir (gandum) yang hijau dan (tujuh) lainnya yang kering agar aku kembali kepada orang-orang itu, agar mereka mengetahuinya. Supaya kamu bertanam tujuh tahun (lamanya) sebagaimana biasa; maka apa yang kamu tuai hendaklah kamu biarkan dibulirnya kecuali sedikit untuk kamu makan."

Dalam tafsir Al-Mishbah, M. Quraish Shihab (Shihab, 2002) menafsirkan bahwa Nabi Yusuf memahami tujuh ekor sapi sebagai tujuh tahun masa pertanian. Boleh jadi karena sapi digunakan membajak, kegemukan sapi adalah lambang kesuburan, sedang sapi kurus adalah masa sulit dibidang pertanian, yakni masa paceklik. Bulir-bulir gandum lambang pangan yang tersedia. Setiap bulir sama dengan setahun. Demikian juga sebaliknya.

Berdasarkan kisah tersebut, bisa dikatakan bahwa pada tujuh tahun kedua akan timbul kekeringan yang dahsyat. Ini merupakan suatu risiko yang menimpa negeri Yusuf tersebut. Namun dengan adanya mimpi sang raja yang kemudian ditakwilkan oleh Yusuf maka kemudian Yusuf telah melakukan pengukuran dan pengendalian atas risiko yang akan terjadi pada tujuh tahun kedua tersebut. Hal ini dilakukan Yusuf dengan cara menyarankan kepada rakyat seluruh negeri untuk menyimpan sebagian hasil panennya pada panenan tujuh tahun pertama demi menghadapi paceklik pada tujuh tahun berikutnya. Dengan demikian maka terhindarlah bahaya kelaparan yang mengancam negeri Yusuf tersebut. Sungguh suatu pengelolaan risiko yang sempurna. Berdasarkan uraian tersebut, dapat dilihat bahwa Nabi Yusuf melakukan proses manajemen risiko melalui tahapan pemahaman risiko, evaluasi dan pengukuran, hingga pengelolaan risiko.

Pada dasarnya Allah SWT telah mengingatkan kepada manusia bahwa apapun yang dilakukan, pasti ada risiko yang akan muncul sehingga manusia harus memiliki upaya-upaya dalam mengatasi kerugian karena risiko tersebut. Developer properti syariah dalam menjalankan kegiatan operasional pembiayaan pemilikan rumah syariah telah sesuai dengan apa yang difirmankan oleh Allah dalam surat Yusuf ayat 46-47 yaitu memiliki mitigasi risiko dalam mengurangi terjadinya risiko dan kerugian akibat risiko yang terjadi. 
Sa'diyah, et al/Jurnal Ekonomi Syariah Teori dan Terapan Vol. 6 No. 9 September 2019: 1814-1829; TEKNIK MITIGASI RISIKO PEMBIAYAAN PEMILIKAN RUMAH (PPR) SYARIAH PADA DEVELOPER PROPERTI SYARIAH

The Committee of Sponsoring Organizations of the Treadway Commission (COSO) Integrated Framework (2004) menyebutkan salah satu dari 4 strategi mitigasi risiko dalam standar manajemen risiko yaitu Reduce (mengurangi risiko) Pengurangan dan pencegahan risiko saling berkaitan erat dan pada dasarnya dapat dicapai dengan cara mengurangi atau menyingkirkan sebagian atau keseluruhan risiko yang ada. Dalam pelaksanaannya ada dua cara yang dapat digunakan, yaitu:

a. Eliminasi (Penghapusan Risiko), yaitu menghapuskan atau megurangi kemungkinan terjadinya risiko yang dihadapi

b. Minimisasi (memperkecil risiko), usaha untuk memperkecil risiko yang dapat dibagi dalam dua bagian, yaitu:

i. Pre Loss Minimisation adalah suatu tindakan memperkecil terjadinya suatu risiko yang dilakukan sebelum terjadinya kerugian.

ii. Post Loss Minimisation adalah suatu tindakan memperkecil terjadinya suatu risiko yang terjadi sesudah terjadinya kerugian.

Berdasarkan hasil penelitian yang dilakukan, dapat dinyatakan bahwa developer properti syariah memiliki teknik mitigasi risiko pada setiap risiko yang dihadapi, baik risiko yang berasal dari customer maupun risiko yang berasal dari perusahaan yaitu dengan cara mengurangi risiko yang akan timbul dan kerugian yang dapat terjadi karena risiko tersebut. Konsep developer properti syariah ini sesuai dengan konsep mitigasi risiko berdasarkan The Committee of Sponsoring Organizations of the Treadway Commission (COSO) Integrated Framework (2004) yaitu konsep Reduce (mengurangi risiko). Ada dua cara yang dilakukan yaitu Eliminasi (menghilangkan risiko) dan Minimisasi (memperkecil risiko). Konsep developer properti syariah dalam emalkukan upaya mitigasi risiko sesuai dengan konsep mitigasi adalah minimisasi (memperkecil risiko) yang terbagi menjadi dua bagian yaitu Pre Loss Minimisation (sebelum terjadinya risiko) dan Post Loss Minimisation (sesudah terjadinya risiko). Developer properti syariah memiliki konsep mitigasi risiko yang juga dilakukan pada saat sebelum terjadinya risiko (kerugian) dan saat sesudah terjadinya risiko (kerugian) pada setiap risiko yang bisa saja terjadi pada pembiayaan pemilikan rumah

(PPR).

Tabel 1.

Ringkasan Mitigasi Risiko Pembiayaan Pemilikan Rumah (PPR) Pada Developer Properti Syariah

\begin{tabular}{|l|l|l|}
\hline \multicolumn{1}{|c|}{ Jenis risiko } & \multicolumn{1}{|c|}{ Uraian Risiko } & \multicolumn{1}{c|}{ Mitigasi Risiko } \\
\hline Risiko gagal bayar & Pre Loss Minimisation & 1.Pembinaan (pengetahuan tentang \\
(terlambat bayar) & & muamalah, product knowledge) \\
& & 2.Interview kepada customer. \\
& & 3. Tanda tangan IJB (Ikatan Jual Beli). \\
\hline
\end{tabular}




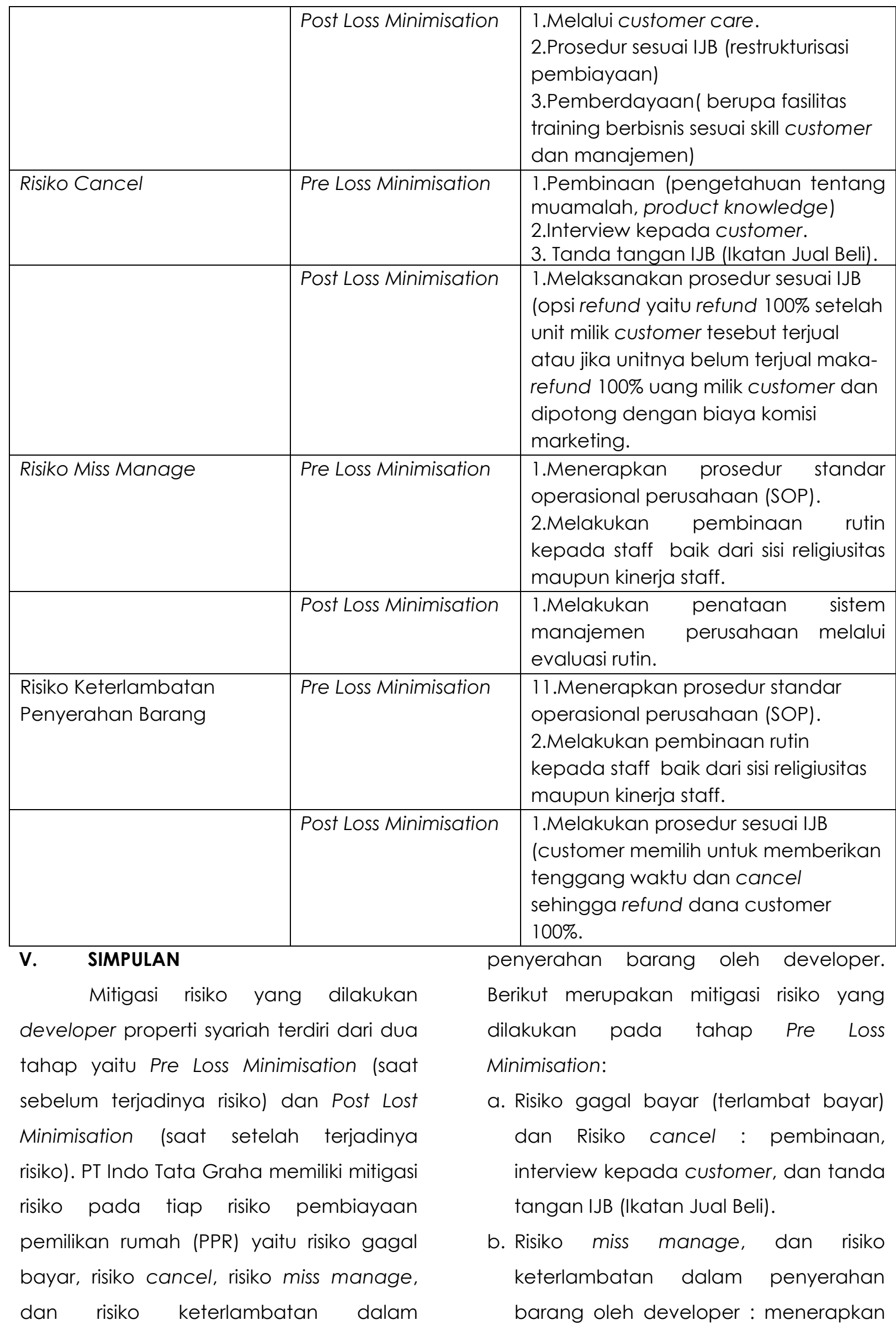


Sa'diyah, et al/Jurnal Ekonomi Syariah Teori dan Terapan Vol. 6 No. 9 September 2019: 1814-1829;

TEKNIK MITIGASI RISIKO PEMBIAYAAN PEMILIKAN RUMAH (PPR) SYARIAH PADA DEVELOPER PROPERTI SYARIAH

prosedur standar operasional perusahaan (SOP) dan melakukan pembinaan rutin kepada staff (tausiyah, mengaji, meeting).

PT Indo Tata Graha juga memiliki mitigasi risiko yang dilakukan pada tahap Post Loss Minimisation sebagai berikut:

a. Risiko gagal bayar (terlambat bayar) : melalui customer care, melaksanakan prosedur sesuai IJB (restrukturisasi), dan pemberdayaan.

b. Risiko cancel : melaksanakan prosedur sesuai IJB yaitu Refund.

c. Risiko miss manage (kesalahan manajemen): Melakukan penataan sistem manajemen perusahaan melalui evaluasi rutin.

d. Risiko keterlambatan dalam penyerahan barang oleh developer: melaksanakan prosedur sesuai IJB yaitu menambah waktu dan refund.

\section{DAFTAR PUSTAKA}

Aditya, Oka dan Prima Naomi. 2017. Penerapan Manajemen Risiko Perusahaan dan Nilai Perusahaan di Sektor Konstruksi dan Properti. Jurnal Bisnis dan Manajemen 7 (2), $167-180$.

Alijoyo, Antonius. 2006. Enterprise Risk Management: Pendekatan Praktis. Jakarta : Ray Indonesia.

Amir, Kurniati. (2017). Peran Agunan Dalam Penyelesaian Pembiayaan Mikro Bermasalah. Skripsi. Universitas Islam Negeri Raden Intan.
Arikunto, Suharsimi. 2003. Manajemen Penelitian. Jakarta : Rineka Cipta.

Badan Pusat Statistik. (2015).

Bank Indonesia. 2011. Peraturan Bank Indonesia No.13/14/2011 tentang Penanganan Pembiayaan Bermasalah.

Bank Indonesia. 2012. Surat Edaran Bank Indonesia No.14/33/DPbS tanggal 27 November 2012 Perihal Penerapan Kebijakan produk Pembiayaan Kepemilikan Rumah dan Pembiayaan Kendaraan Bermotor bagi Bank Umum Syariah dan Unit Usaha Syariah.

Dorian, Lisa. 2011. Understanding Risk Mitigation. Industry Insight: A Newsletter for CAs in Industry. Publish by the Institute of Chartered Accountants of British Columbia.

Firrizqi, Alfinia. 2018. Manajemen Risiko Pembiayaan Pemilikan Rumah (PPR) Non Bank oleh Developer (Studi Kasus: Sabrina Azzura Bekasi). Skripsi. Universitas Airlangga.

https://tafsirq.com/31-luqman/ayat34\#tafsir-quraish-shihab (diakses pada 5 Februari 2019).

Idris, Munadi. 2014. Implementasi Pembiayaan Pemilikan Rumah (PPR) Syariah Studi Kasus Pada Griya Ar-Roya Di Kota Makassar. Tesis. Pascasarjana UIN Makassar. 
Sa'diyah, et al/Jurnal Ekonomi Syariah Teori dan Terapan Vol. 6 No. 9 September 2019: 1814-1829;

TEKNIK MITIGASI RISIKO PEMBIAYAAN PEMILIKAN RUMAH (PPR) SYARIAH PADA DEVELOPER PROPERTI SYARIAH

Ismail. 2010. Manajemen Perbankan dari Teori Menuju Aplikasi.Jakarta : Kencana.

Khan, Tariqullah and Habis Ahmed. (2008). Manajemen Risiko Lembaga Kevangan Syariah. Jakarta: Bumi Aksara.

Kountur, Ronny. 2008. Mudah Memahami Manajemen Risiko Perusahaan. Jakarta: PPM.

Lestari. 2014. Risiko Pembiayaan Dalam Akad Istishna Pada Bank Umum
Syariah, Jurnal Hukum dan Ekonomi Syari'ah, 2 (1).

Nawawi. 1990. Metode PenelitianBidang Sosial. UGM Press.

Rustam, B. R. 2013. Manajemen Risiko Perbankan Syariah di Indonesia. Jakarta: Salemba Empat.

Shihab, M. Quraish. 2002. Tafsir Al-Mishbah. Jakarta : Lentera Hati 2.

Undang-Undang Negara Republik Indonesia No.10 Tahun 1998 tentang Perbankan Pasal 1 ayat 2. 